\title{
Modeling Currency Flow in an Economy: The Case of India's Demonetization in 2016
}

\author{
Frederick Betz*, Timothy R. Anderson, Aurobindh Kalathil Puthanpura \\ Portland State University, Portland, USA \\ Email: ^fbetz@venture2reality.com
}

How to cite this paper: Betz, F., Anderson, T.R. and Puthanpura, A.K. (2017) Modeling Currency Flow in an Economy: The Case of India's Demonetization in 2016. Theoretical Economics Letters, 7, 1001-1014. https://doi.org/10.4236/tel.2017.74068

Received: April 28, 2017

Accepted: June 19, 2017

Published: June 22, 2017

Copyright $\odot 2017$ by authors and Scientific Research Publishing Inc. This work is licensed under the Creative Commons Attribution International License (CC BY 4.0).

http://creativecommons.org/licenses/by/4.0/

\begin{abstract}
The 2016-2017 economic event of a sudden demonetization in India can provide an empirical example in which to test the validity of some schools of monetary theory, particularly the Chartalist School. The Chartalist School distinguished three kinds of money: Fiat, Commodity, and Managed Money. The event provided empirical evidence that this distinction between currencies in an economy is valid and important. The sudden withdrawal of Fiat money immediately decreased the amount of commodity money, creating an economic crisis in local Indian commerce. Managed money, as bank accounts, was unable to fill the temporary gap in the supply of money because a large portion of the Indian population did not have bank accounts. Also the government did not supply a sufficient number of new 500 and 2000 rupee notes to quickly replace the withdrawn 500 and 1000 rupee notes.
\end{abstract}

\section{Keywords}

Economics, Financial Systems, Monetary Theory, Methodology

\section{Introduction}

Monetary theory is a major topic in economics with a long tradition and with several schools of theory. As summarized by L. Randal Wray, monetary theory identifies three kinds of money: "Fiat Money, Commodity Money, and Managed Money" [1]. Fiat money issued by government is a form to collect taxes; taxes must be paid in money issued by a government, fiat money. Commodity money is the currency used in trade and commerce. Managed money is bank accounts used to settle debt and credit transactions in trade. The validity of any theory can be tested by how the models derived in the theory are compared to empirical reality. The validity of monetary theory is important because of the monetary and fiscal policies implemented upon the basis of theory. Empirical tests of monetary 
theory occur in the economic histories of countries. The economic event in 2016 of the demonetarization of the lesser notes of the Indian rupee provided an economic event-in which to study the empirical interactions of fiat, commodity, and managed money in an economy.

\section{Historical Case: Demonetization of the Indian Rupee in 2016}

The demonetarization of the Indian Rupee in 2016 is a kind of political-economic experiment. John Lanchester wrote: "Two months ago, the world's largest democracy embarked on one of the biggest monetary experiments the world has ever seen. On Nov. 8, without warning or preamble, without discussion papers or leaks, Narendra Modi's Indian government invalidated most of the country's cash. The 500- and 1000-rupee notes ... were, as of that moment, no longer legal tender. Anyone in possession of these notes had until Dec. 30 to take them to a bank and either deposit them or exchange them for other notes. Anyone presenting more than 250,000 rupees in cash $(\$ 3700)$ had to provide an explanation for why he had so much, and proof that he had paid tax on it; the penalty for unpaid tax was to cough up 200 percent of the amount owed. The two retired notes represented 86 percent, by value, of all the cash in circulation in India" [2].

Shashi Tharoor wrote: “On November 8, Indian Prime Minister Narendra Modi announced that, at the stroke of midnight, some 14 trillion rupees worth of 500- and 1000-rupee notes- $86 \%$ of all the currency in circulation-would no longer be legal tender. With that, India's economy was plunged into chaos. Modi's stated goal was to make good on his campaign pledge to fight 'black money': the illicit proceeds-often held as cash-of tax evasion, crime, and corruption. $\mathrm{He}$ also hoped to render worthless the counterfeit notes reportedly printed by Pakistan to fuel terrorism against India. Nearly a month later, however, all the demonetization drive has achieved is severe economic disruption" [3].

The significance of this event in India provides an empirical case to understand the role of money in a modern economy, not just in India's economy. John Lanchester further wrote: "Many Westerners have become so used to discussing China as the most populous country in the world, with 1.357 billion inhabitants that they forget India is just behind it, with 1.252 billion. Of that total, only 12 million pay income tax. That's an astonishing number: 99 percent of Indians don't pay tax. The majority of Indians work in what economists call the informal' or 'unorganized' economy, which runs overwhelmingly on cash. The short-term result of Modi's move has been, unsurprisingly, chaos: huge lines at A.T.M.s and banks, farmers unable to buy seeds to plant crops, weddings and property transactions canceled, piles of illicit cash shredded or burned. Some workers have been forced to choose between earning a day's pay or spending the same day waiting to deposit money in a bank. Many of the poor don't have bank accounts at all" [2].

The rupee currency is fiat currency, issued or withdrawn by a government. However, in formulating the policy to withdraw the fiat notes, the Prime Minis- 
ter had not anticipated the impact upon the commodity money of India. Shashi Tharoor wrote: "Far from being a masterstroke, Modi's decision seems to have been a miscalculation of epic proportions. The announcement immediately triggered a mad scramble to unload the expiring banknotes. Though people have until the end of the year to deposit the notes in bank accounts, doing so in large quantities could expose them to high taxes and fines. So they rushed to gas pumps, to jewelry shops, and to creditors to repay loans. Long queues snaked in, out, and around banks, foreign-exchange counters, and ATMs-anywhere where people might exchange the soon-to-be-defunct notes. But, upon getting to the front of the line, people were often met with strict withdrawal limits, because, in a display of shocking ineptitude, not enough new currency was printed prior to the announcement. Worse, the new notes' design prevents them from fitting into existing ATMs, and their denomination-2000 rupees-is too high to be useful for most people, especially given that the government's failure to print enough smaller-denomination notes means that few can make change" [3].

It is important to distinguish between the functions of money as fiat (taxes) and commodity (trade) because, in all cases, money is a kind of "ticket" to an activity, to a "performance". For example, John Maynard Keynes wrote: "Money is the measure of value, but to regard it as having value itself is a relic of the view that the value of money is regulated by the value of the substance of which it is made, and is like confusing a theatre ticket with the performance" [4].

Money, both as ticket and as performance, was highlighted in the case of India. Geeta Anand and Hari Kumar wrote: "The ban is intended both to curb the flow of counterfeit money and to take aim at terrorist organizations that rely on unaccounted-for cash. It is also expected to help the government clean up a system that has relied on cash to pay bribes and to avoid taxes. But the announcement, made on national television in both Hindi and English, led to an immediate upheaval in the country. Abolishing the current version of the 500 and 1000 rupee notes, worth about $\$ 8$ and $\$ 15$, will effectively remove 80 percent of the currency in circulation" [5].

These rupee notes of 500 and 1000 were principally used as commodity money in commercial trade within India. Hence, at least $80 \%$ of the trade in the Indian economy was impacted. Geeta Anand wrote: "Under the plan, people are allowed to exchange the old bills for new ones of 500 and 2000 rupees, but only at banks or post offices, where their exchanges will be monitored and anyone with a large amount of cash will have to explain its source. The changes, meant to combat corruption and tax avoidance, have thrown the country into chaos" $[6]$.

Economic "chaos" was not the intention of the government for the policy change. But in fact, "chaos" was the "performance". What was the intention? Geeta Anand wrote: "The idea was to expose and penalize people holding huge amounts of cash they could not account for, primarily money on which taxes have not been paid. Most of the so-called black money is held in 500- and 1000-rupee notes. Someone who goes to a bank or post office with more than 
250,000 rupees in cash, or about $\$ 3700$, has to explain the source of the money to the tax authorities. People who can explain how they earned the money and show that taxes were paid can keep it. But those without a good explanation will have to answer to the tax authorities" [6].

Why had the government not anticipated the impact of the withdrawal of fiat money on the trade with commodity money? Geeta Anand further wrote: "Overnight, people found themselves lacking the currency for basic transactions, like buying food, fuel and other necessities. Retail businesses came to a standstill because people hoarded the little cash they had for food and other needed supplies. To avoid tipping off tax cheats, the government did not print the new bills until after the announcement, nor did it recalibrate automated teller machines to dispense the new 500- and 2000-rupee notes. Long lines formed at the few A.T.M.s that were operating, and many ran out of bills, infuriating those who had stood in line for hours. Since then, the printing presses have churned out more than $\$ 40$ billion in currency, but the government was initially forced to limit A.T.M. withdrawals to 2000 rupees, or about \$ 30, at a time. The limits are now 2500 rupees per A.T.M. withdrawal and 24,000 a week from a bank. The government says it will take three weeks to recalibrate India's estimated 200,000 A.T.M.s" [6].

Fiat money was a real problem to the government, because few taxes were being paid, with less than $1 \%$ of the populace paying taxes. Geeta Anand wrote: "Unaccounted-for cash, or black money, is a huge problem for the country, because it keeps money out of banks where it could be lent to others, helping businesses grow and driving economic growth. Black money also sharply reduces the taxes collected by the government, and hence services available to the public. About a third of business in India is done with black money. In a heavily regulated economy, businessmen frequently bribe government officials into giving them licenses and other approvals. Government officials invest much of this money in real estate, then understate the amount they actually paid. So not only is the property purchased with black money, but the sellers pay less tax than they should because the prices have been understated. Routine transactions, like paying a hairdresser, are largely carried out off the books to avoid paying taxes" [6].

The "performance" of the event continued on, after November 2016. Geeta Anand wrote: "Will Mr. Modi pay a political price? Indians have exhibited remarkable patience with the currency ban, but only on the promise that it will actually accomplish what he says it will and the government can quickly get the new bills into circulation. The government is working feverishly to distribute them, but lines and public frustration are growing ... The ban could end up substantially damaging Mr. Modi's own promise of jobs and economic development" [6].

And the people who paid the economic price of the event were not the wealthy in India but the merchant, working, and farming groups. Geeta Anand and Hari Kumar wrote: "In the winding lanes of Chawri Bazar, one of Delhi's oldest wholesale markets, paper merchants sat slumped in their stores, pondering how 
to make the transition to the new economic order ushered in by the Indian prime minister two weeks ago. 'This is like curse of God on us,' said Gian Prakash Gupta, 60, a soft-spoken paper wholesaler who was crammed into a closetsize office this week with two other men, three hanging statues of Hindu gods and stacks of broadsheet paper. The power was out, despite the garlands of electric wire that hung over streets too narrow for cars, and Mr. Gupta lamented, 'We do not know how to use computers, how to do online transactions, how to use card-swiping machines.' The business of traders like Mr. Gupta, whose operations lie partly in the vast informal economy that makes up around 20 percent of India's gross domestic product and more than 80 percent of its employment, has been virtually paralyzed since Nov. 8 ..." [7].

About employment, Geeta Anand and Hari Kumar also wrote: "Day laborers were waiting for work this month in Gauhati, India ... As is common in India, the workers said that although they had worked on Hero MotoCorp's shop floor, wearing company uniforms, they had been formally employed by other contractors, meaning they could be let go more easily without benefits. Sunil Kumar, 28, who had been earning 15,000 rupees a month, about \$220, at Hero, said he had been supporting his wife and two children when he lost his job without notice Nov. 29. They immediately cut milk, green vegetables and fruit from their diets, including for their 3-month-old and 3-year-old children ... 'This is like a massacre for us,' he said. 'My livelihood is gone after the cash ban. What do I do now?' ... In Noida, a satellite city of New Delhi, hundreds of unshaven men in rumpled clothing stood recently at a three-way intersection called Khoda Labor Chowk that is a gathering place for people seeking work. Before the currency ban, they told us, they would be hired most days, earning 400 to 600 rupees, about $\$ 6$ to $\$ 9$, for a day of carpentry, floor tiling or masonry. But since the ban, most interviewed said, they had worked for only a week each month, at best, and even on the few days when they were hired their wages had fallen by half" [8].

The demonetarization also impacted consumer prices. Geeta Anand and Hari Kumar wrote: "The decline in vegetable demand is so steep that the prices of eggplants, potatoes, cauliflower and tomatoes dropped between 42 percent and 78 percent (the NCDEX Institute of Commodity Markets and Research said). In the first month alone after the currency ban, micro and small-scale service industries cut staff by 35 percent (the All India Manufacturers' Organization said, based on a survey). It released a study this month saying that job losses in a variety of industries, including automobile parts, infrastructure and construction, would swell to as much as 35 percent by March. Most economists believe the economy will rebound, but nobody knows how long it will take" [8].

By the middle of March 2017, it became evident that Modi's political party (and India) would survive the economic crisis. On March 14, 2017, Amy Kazmin and Simon Munday wrote: "When Indian banks open today, the era of cash rationing that followed Narendra Modi's cancellation of most of the county's currency will have come to an end ... The severe liquidity squeeze has already eased. India's supply of legal tender in circulation has risen to $\$ 158 \mathrm{bn}$, mostly in 
freshly printed Rs 500 and Rs 2000 notes ... 'A lot normality has already come into the market,' said Romesh Sobti, chief executive of InsusInd Bank. 'You don't see queues for cash anywhere' ... However, private banks such as Axis Bank, HDFC and ICICI are still trying to damp the hunger for cash, with new fees on cash transactions ..." [9].

\section{Case Analysis}

One can use an analytical framework of the cross-disciplinary societal perceptual space in order to analyze the case, as to key societal factors in the historical event, shown in Figure 1 [10].

Applying this to the demonetarization event, the key factors of the event are inscribed in the graphic box, as shown in Figure 2.

INDIVIDUAL_Prime Minister Narendra Modi.

SOCIETY-The society is the Indian nation, in which about one third of the economy conducts commercial transactions in cash. It is also a heavily regulated economy, with government bribery common and frequent.

ACTION-Prime Minister Narendra Modi demonetarized two Indian currency bills of 500 and 1000 rupees, allowing (over a finite period) people to exchange the old bills for new ones of 500 and 2000 rupees at banks or post offices. However, the policy was implemented without the government preparing for it. When people went to the banks to exchange rupee notes, the banks quickly ran out of cash. People stood in lines, but were still not able to exchange notes. The economy nearly stopped, since $80 \%$ of commercial transactions were in cash. But then unable to be exchanged, the currency crisis continued for three months.

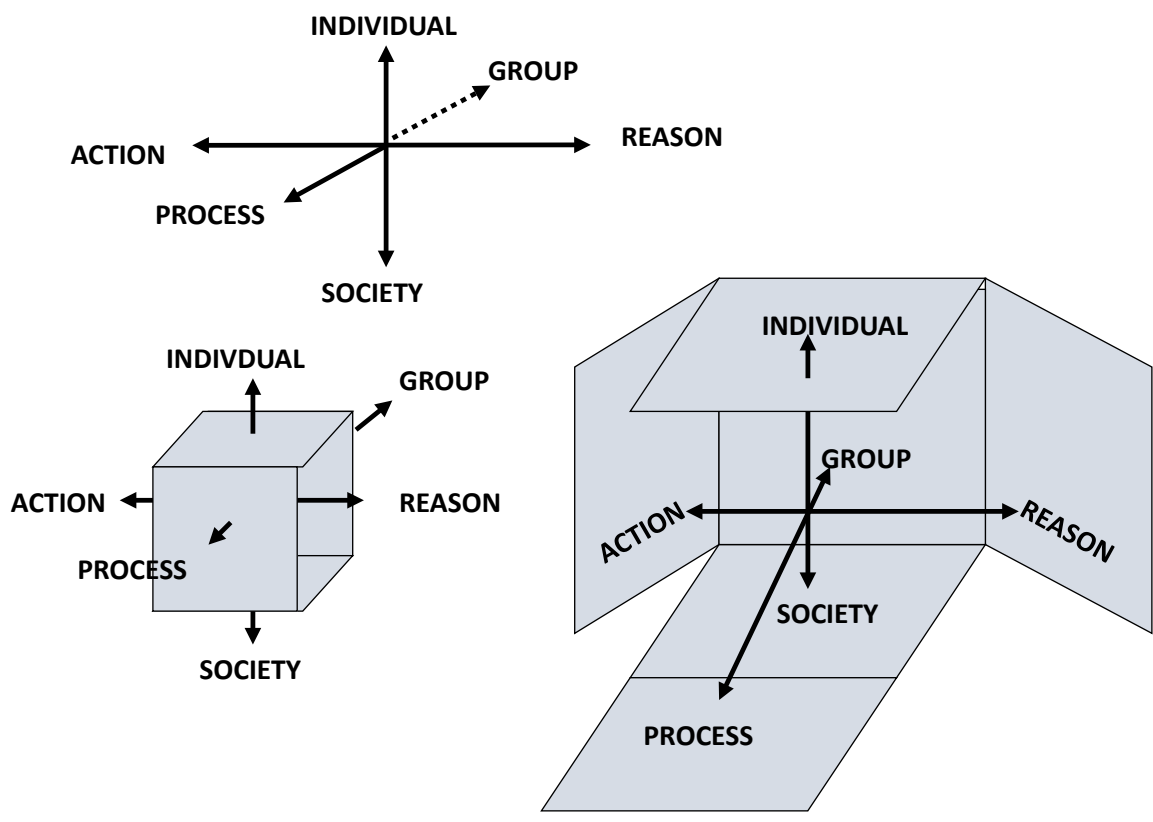

Figure 1. Societal perceptual-space event box interactions of an individual \& society are mediated through reason $\&$ action and through groups $\&$ processes. 


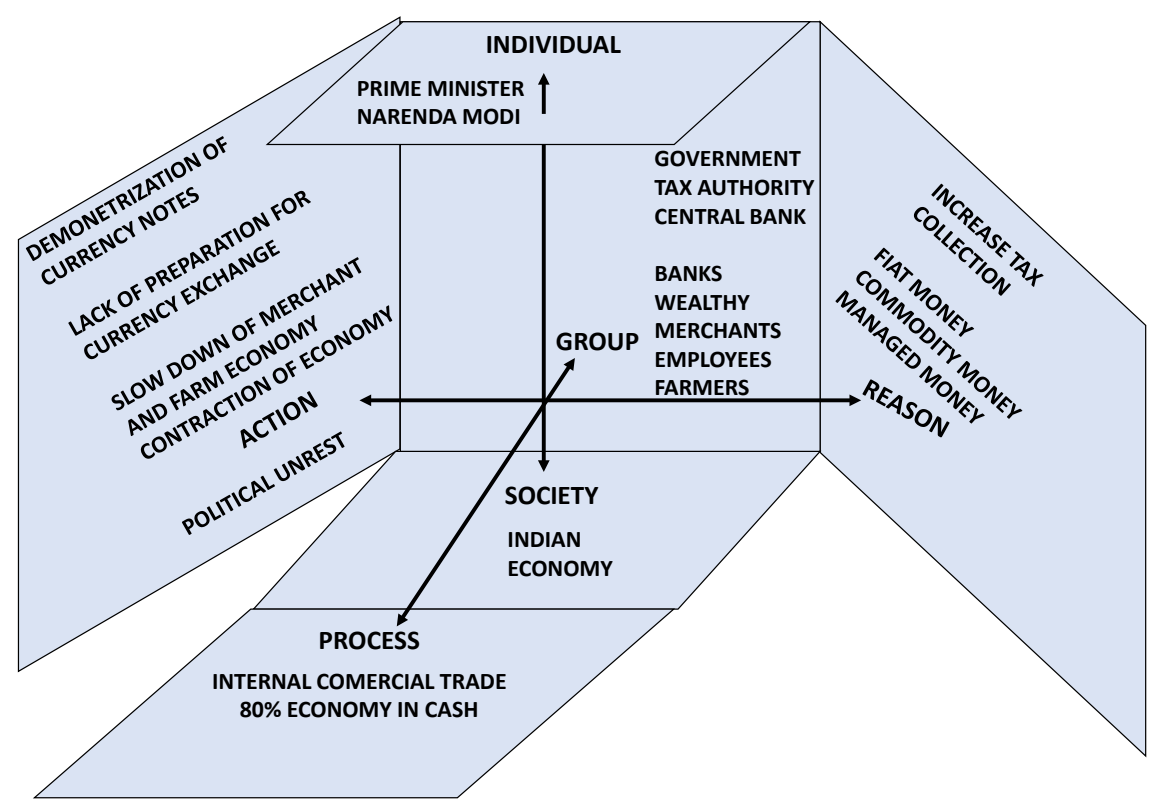

Figure 2. India demonetarization 2016.

REASON-Modi's plan was to collect taxes on monetary transactions in the "black market" where taxes are not paid on transactions. He wished to expose and penalize people who were holding large amounts of cash in 500 and 1000 rupee notes. If people attempted to exchange more than 250,000 rupees (about $\$ 3700$ ), they would have to explain the source to tax authorities. If they could explain how the money was earned and taxes were paid on it, they could keep it, otherwise not. However, the plan did not include the interaction between fiat money and commodity money in India. The government had issued fiat money, intended to pay taxes; but it was also used as commodity money for commercial trade.

GROUP-The groups involved were the Indian government, central bank, local banks, small merchants, Indian wealthy, Indian middle-class, and Indian employees and farmers.

PROCESS-Process was the termination of currency notes of 500 and 1000 rupee and replacement with new 500 and 2000 rupee notes. The process did not go smoothly because (1) replacement currency notes were not ready in time and (2) many Indians do not have bank accounts and (3) there were limits on the withdrawal of money. Also (4) the ATMs were not quickly recalibrated for the new currency nor supplied sufficiently with it.

In summary, the Action (demonetization) did not provide the results intended by the Reason (to increase taxes). This was because in the Process (commercial transactions), the fiat currency (500 and 1000 rupee notes) had been providing two functions in Indian society: fiat money to pay taxes and commodity money to facilitate trade in the cash-based economy. Because of the government's lack of appreciation between these two functions, the withdrawal of fiat money (500 and 1000 rupee notes) also removed the commodity money from the cash-based trade. Thus the immediate impact of the demonetarization was economic chaos 
in a principally cash-based economy-with the impact falling heavily on the poor and middle classes but not upon the wealthy.

Shashi Tharoor wrote: "India's previously booming economy has now ground to a halt. All indicators-sales, traders' incomes, production, and employmentare down. Former Prime Minister Manmohan Singh estimates that India's GDP will shrink by $1 \%-2 \%$ in the current fiscal year. But, as is so often the case, the impact is not being felt equally by all. India's wealthy, who are less reliant on cash and are more likely to hold credit cards, are relatively unaffected. The poor and the lower middle classes, however, rely on cash for their daily activities, and thus are the main victims of this supposedly 'pro-poor' policy. Small producers, lacking capital to stay afloat, are already shutting down. India's huge number of daily wage workers can't find employers with the cash to pay them. Local industries have suspended work for lack of money" [3].

Finance in the agriculture sector was particularly affected. Shashi Tharoor also wrote: "The informal financial sector-which conducts $40 \%$ of India's total lending, largely in rural areas-has all but collapsed. India's fishing industry, which depends on cash sales of freshly caught fish, is wrecked. Traders are losing perishable stocks. Farmers have been unloading produce below cost, because no one has the money to purchase it, and the winter crop could not be sown in time, because no one had cash for seeds ... Hospitals are turning away patients who have only old banknotes; families cannot buy food; and middle-class workers are unable to buy needed medicine. As many as 82 people have reportedly died in cash queues or related events. Furthermore, it seems likely that many of the short-term effects of the demonetization could persist-and intensify-in the longer term, with closed businesses unable to reopen. It could also cause lasting damage to India's financial institutions, especially the Reserve Bank of India, whose reputation has already suffered" [3].

Moreover the government's goal of decreasing "black money" might not be achieved. Shashi Tharoor wrote: "Perhaps the worst part is that these sacrifices are not likely to achieve the government's stated goal. Not all black money is in cash, and not all cash is black money. Those who held large quantities of black money seem to have found creative ways to launder it, rather than destroying it to avoid attracting the taxman's attention, as the government expected. As a result, most of the black money believed to have been in circulation has now flooded into banks, depriving the government of its expected dividend. On top of all of this, the government's plan does nothing to control the source of black money. It will not be long before old habits-under-invoicing, fake purchase orders and bills, reporting of non-existent transactions, and blatant briberygenerates a new store of black money" [3]. Black money' is fiat money used in economic transactions, which is not taxed.

\section{Analysis and Theory: Types of Money}

L. Randall Wray wrote: "In conventional analysis, money is used to facilitate exchange; its value is supposed to have been long determined by the value of the 
precious metal it represented, although under a fiat money system its value is said to be determined by the quantity of commodities it can purchase. This, in turn, is a function of the rate of inflation, which is presumed to be under the control of the central bank. In this view, monetary policy has to do, primarily, with control of the money supply, while fiscal policy has to do with government spending, taxing and borrowing. This is quite different from the Chartalist approach, which can be traced from Adam Smith through to John Maynard Keynes ... In the Chartalist approach, money is a creature of the state ... The government does not 'need' the public's money in order to spend; rather, the public needs the government's money in order to pay taxes" [1].

In the Chartalist view, the government issues money principally as a way for the public to pay taxes. This is effective; for if a citizen does not pay taxes, the government can imprison the citizen. However in an economy, the function of money for paying taxes is not its only function. Money also functions in commodity trade, facilitating the private economy-commodity money. If the government fiat money is stable, not undergoing high inflation, then it can serve also as commodity money. Under high inflation, fiat money becomes worthless as commodity money. (For example, this happened to the German mark in the 1920s, when the Weimar government printed large volumes of money to pay reparations to the French and British goverments.)

The Chartalist view does help explain the role of money in the Indian economy in 2016-17. In the event of India's demonetarization, the government did act to increase taxes-so the Chartalist theory on money was valid in this event. The fiat currencies of the $500 \& 1000$ rupee notes were withdrawn by the government because they were being used not as Fiat Money but as Commodity Money. But the government did not appreciate that a sudden withdrawal of the fiat money would bring a halt to the commercial markets-because the fiat money was also being used as commodity money in the $80 \%$ cash economy. This is evidence that the monetary policy in an economy should include the Chartalist perspectivethat currency serves several functions as money in a society-the functions of fiat, commodity, and managed monies.

Banks also impact the quantity of money through the issuance of credit. In the Indian case, the government overestimated the role of Managed Money (as bank accounts) in the economy-the extent of bank accounts were in use by the populace. Bank accounts are one form of Managed Money in an economy, expanding or shrinking credit in an economy. L Randall Wray wrote: "Hyman Minsky presented a view of money that was based on the Chartalist approach ... For the most part, bank money is created as banks 'make loans'. Money is unique in that it is created in the act of financing by a bank and is destroyed as the commitments on debt instruments owned by banks are fulfilled. Because money is created and destroyed in the normal course of business, the amount outstanding is responsive to the demand for financing ... The banks, when their customers apply to them for money, generally advance it to them in their own promissory notes (i.e. bank checking accounts) ... Because notes (bank checks) 
circulate as if they were money, the banker need hold only a fractional reserve against them" [1].

In addition to governments issuing Fiat money for tax payments, banks also affect the quantity of money through the issuance of credit. In the Indian case, the government overestimated the role of Managed Money in the economy. The Indian government did not fully appreciate the extent of bank managed money in the economy-useful to $20 \%$ of the economy but not to the $80 \%$ of the Indian economic agents (farmers and laborers who did not have bank accounts and so could not deposit their demonetarizing rupee notes in bank accounts). Geeta Anand and Hari Kumar wrote: "The worst affected by the cash crunch are the country's hundreds of millions of farmers, produce vendors, small shop owners and daily-wage laborers who are usually paid in cash at the end of a day's work" [8].

L. Randall Wray wrote: "In recent years, many theorists have contributed to the development of an 'endogenous money' approach that is in many respects related to the Chartalist position ... There are two fundamental precepts of the endogenous money view: (1) the 'supply' of money generally expands to meet the 'demand' for money; and (2) the central bank has no direct, discretionary, control over the quantity of money. To some extent ... most economists (until the present century) at least implicitly adopted an endogenous money approach. It is only in this century that the majority of economists have come to accept the 'exogenous' money view that the central bank can directly control the quantity of money and that the money stock can be taken to be 'fixed' such that it does not respond to 'money demand'" [1].

The economic event of Indian demonetarization does not supply empirical evidence about an endogenous or exogenous money view - as these consider the relation of supply to demand of money over a long term. However, in a very short term, an act by a government (such as sudden demonetarization) can impact both the supply and demand of money. The immediate flow of commodity money in an economy can be impacted by sudden changes in fiat money in an economy.

\section{Institutional Explanations in the Demonetarization Societal Event}

We continue the analysis of the demonetarization event, in terms of understanding the connections between policy and performance in a society. For this we continue to use the societal dynamics depiction of explanations (between key factors in an historical event). Figure 3 shows that in a graph format, the connections between six dimensions of the societal perceptual space can provide fifteen kinds of explanations possible in a societal event.

The directional controls in any society occur at three levels in the graphic representations of societal explanations: Control in a Managed System, Control in a Socio-Technical System, and Control in a Self-Organizing System. The Managed System in the economic event was the Government of India; the Socio-Technical System was Money; and the Self-Organizing System was the Indian economy. 


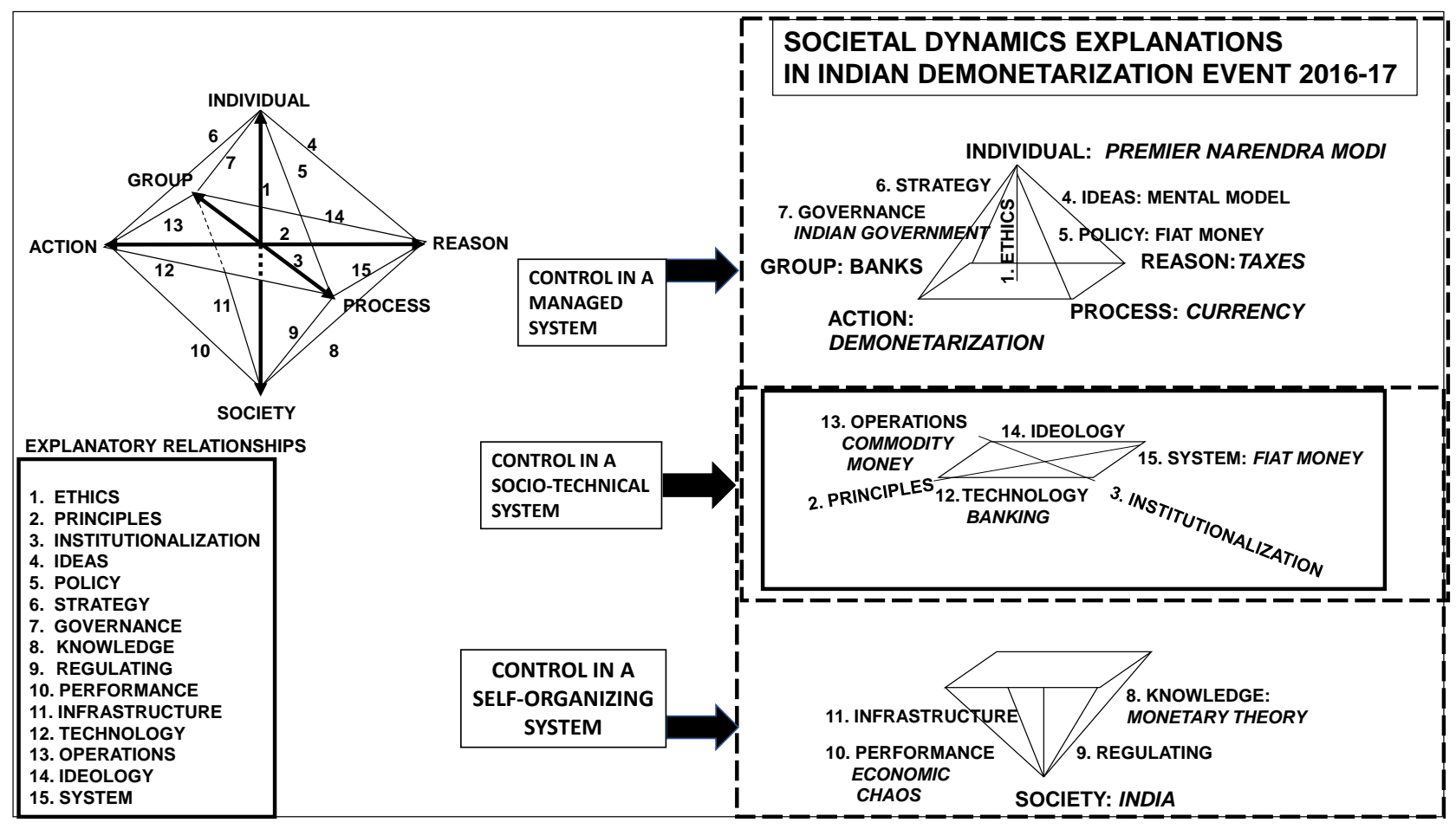

Figure 3. Directional controls in a society.

Managed System of Government:

"Governance" by the Indian government initiated an "Action" of Demonetarization under the Individual' of Premier Narendra Modi by a new "Policy" involving Fiat Money. Modi's "Reason" was to increase collection of Taxes, and his "Idea" was a Mental Model of how currency and taxes interacted. The "Process" involved was Currency.

Socio-Technical System of Money:

The "System" of Money enabled the "Operations" of Commerce in $80 \%$ of the cash economy, facilitated by the "Technology" of Banking.

Self-Organizing System:

With an imperfect "Knowledge" of Monetary Theory, the "Action" of Demonetarization resulted in a temporary societal "Performance" of Economic Chaos.

\section{Conclusions}

The 2016-2017 economic event of a sudden demonetarization in India provides an empirical example in which to test the validity of some schools of monetary theory, particularly the Chartalist School. In the case of India, the Chartalist School distinguished three kinds of money: Fiat, commodity, and managed money. The event provides empirical evidence that this distinction between the currencies in an economy is valid and important. The sudden withdrawal of Fiat money decreased immediately the amount of commodity money, creating an 
economic crisis in local Indian commerce. Managed Money was unable to fill the temporary gap in the supply of money because a large portion of the Indian population did not have bank accounts.

Figure 4 shows the principle explanations in the social-technical system of money in the demonetarization event.

This analysis of the event emphasizes that money in the Indian society functioned as a technical system of society (socio-technical system) in the societal Process of Currency. Therein, the two functions of money were as a System of Fiat Money and as an Operation of Commodity Money, which were connected through the Technology of Banking. This way of analyzing the money system emphasizes how the two functions of money are connected through the Technology of the Banking institutions. But Banking connected the two functions of Currency in only $20 \%$ of the population. The economic chaos resulting from the policy of sudden demonetarization was due to the lack of banking to extend to all the population ( $80 \%$ of the society). The Knowledge of the Mental Model only focused on the cash markets in the economy, Black Market, rather than upon any valid Monetary Theory.

This analysis emphasizes what went wrong with the government policy. Was it bad implementation of good policy or bad implementation of bad policy? It was both. The policy was imperfect because the Mental Model of the Individual of the policy maker apparently did not consider the interactions between fiat and commodity money in the principally cash economy of India. The implementation was imperfect because not all the society had banking accounts to accomplish the transition of money, and the government did not print a supply of the new money before implementing the policy. As Shashi Tharoor concluded:

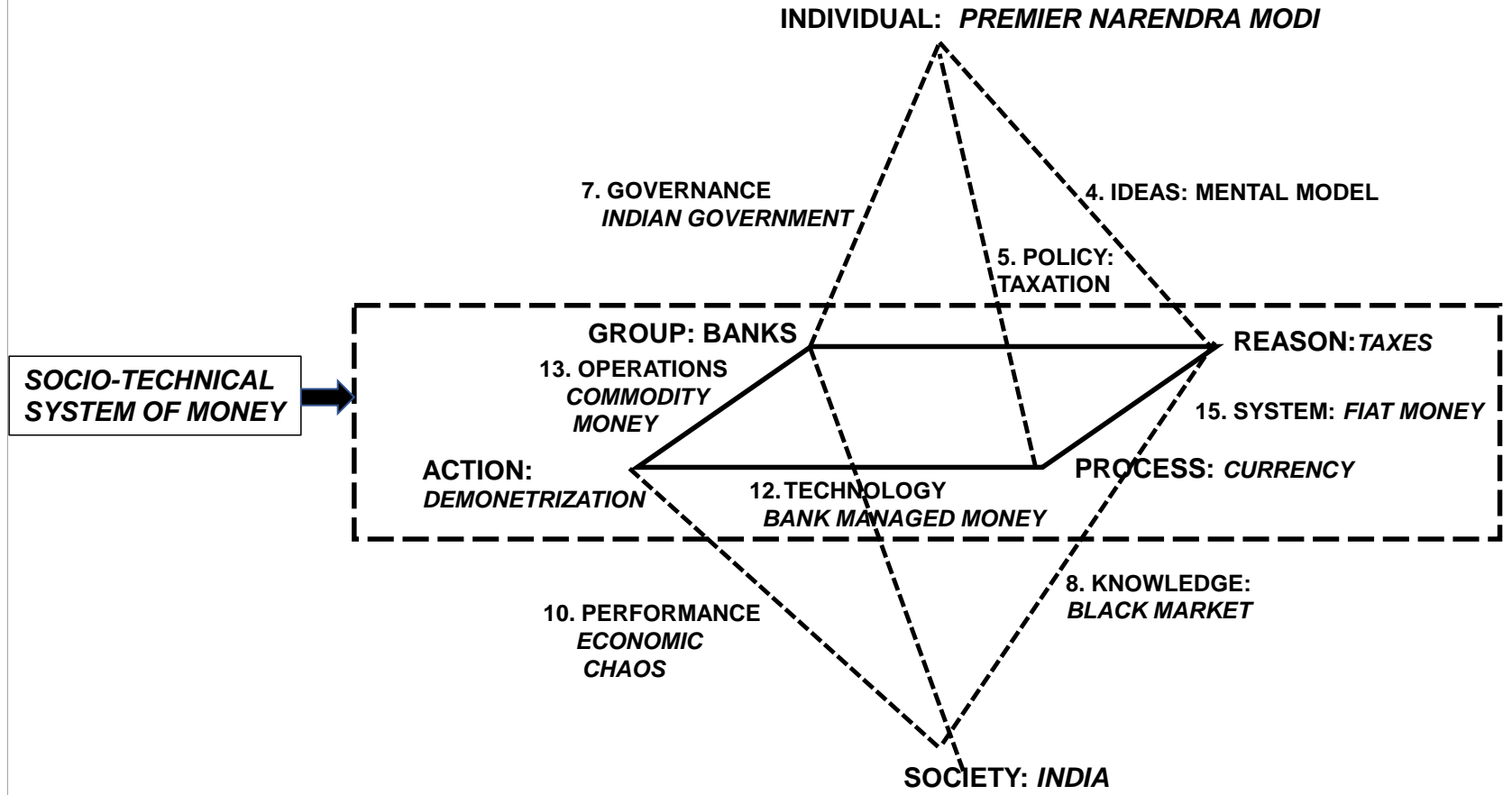

Figure 4. Descriptive form: actual socio-technical system of policy to address taxation issues. 
"Many Modi supporters claim that the demonetization policy's problems are a result of inept implementation. But the truth is that its design was fundamentally flawed. There was no 'policy skeleton', no cost-benefit analysis, and no evidence that alternative policy options were considered. Judging by the blizzard of policy tweaks since the announcement, it seems clear that no impact study was carried out" [3].

However, the economic crisis did motivate the government to attend to public good. Geeta Anand wrote: "Trying to spur an Indian economy hard hit by its cash shortage, the government of Prime Minister Narendra Modi unveiled plans on Wednesday for next year's budget that would significantly increase spending on infrastructure, rural areas and antipoverty programs ... The budget also cuts income taxes to 5 percent from 10 percent for people making between $\$ 3700$ and $\$ 7400$ annually. But he imposed a 10 percent surcharge on higher-income taxpayers ... Much of the spending in rural areas will go to building roads, with the aim of increasing efficiency and access to markets while providing jobs, Mr. Joshi said. The budget also substantially increased India's expenditure on its rural employment program, to $\$ 710$ million, the highest ever ... But the main thrust of the government budget on Wednesday was to try to help the economy, which has been hurt by Mr. Modi's cash ban, by most accounts. The International Monetary Fund cut its predicted growth rate for India by one percentage point this year to 6.6 percent, in large part because of the currency ban" [11].

From this kind if institutional analysis of the societal event which societal dynamics provides, what prescription could one suggest about the policy (except demonetarization) that the Indian government should have followed? Figure 5 shows the institutional explanations in a prescriptive form (rather than in the descriptive form of the earlier Figure 4).

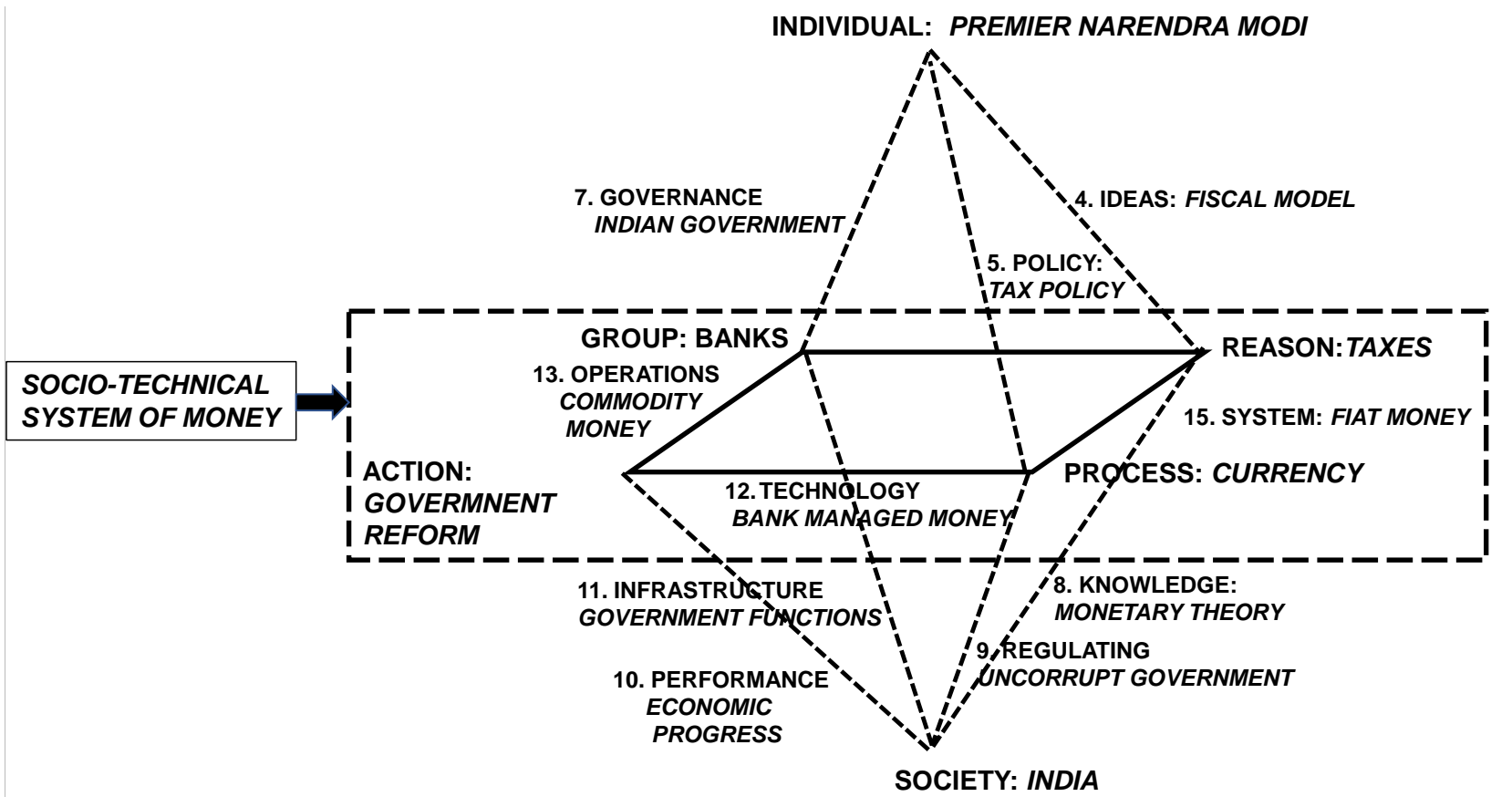

Figure 5. Prescriptive form: socio-technical system of money in a prescriptive demonetarization event. 
The Action should have been Government Reform, instead of demonetarization. In this prescriptive societal depiction, the governmental leadership of the Individual Modi should have focused Policy upon Tax Policy using an Idea of a valid Fiscal Model. The government should focus upon reform Regulating toward an Uncorrupt Government, wherein the populace appreciate that taxes pay for a just and effective government, without bribery. Knowledge should be based upon a valid Monetary Theory. The point of government is to build an Infrastructure providing effective Government Functions so that the private markets can create the Performance of Economic Progress in the country.

In a next paper, we will describe a model of a government fiscal policy, which is appropriate to and valid for this case of contemporary India.

\section{References}

[1] Wray, R. (1998) Understanding Modern Money: The Key to Full Employment and Price Stability. New Economic Institute.

[2] Lanchester, J. (2017) Should We Trash Cash? New York Times, January 10. https://www.nytimes.com/2017/01/10/magazine/should-we-trash-cash.html

[3] Tharoor, S. (2016) India's Demonetization Disaster. Project Syndicate, December 6. https://www.project-syndicate.org/commentary/india-demonetization-policy-conse quences-by-shashi-tharoor-2016-12

[4] Keynes, J.M. (2016) The General Theory of Employment, Interest, and Money. McGraw-Hill, Pennsylvania Plaza.

[5] Anand, G. and Hari, K. (2016) Narendra Modi Bans India's Largest Currency Bills in Bid to Cut Corruption. New York Times, November 8.

https://www.nytimes.com/2016/11/09/business/india-bans-largest-currency-bills-fo r-now-n-bid-to-cut-corruption.html

[6] Anand, G. (2016) How Narendra Modi of India Plans to Wipe Out "Black Money". New York Times, November 14

https://www.nytimes.com/2016/11/15/world/asia/how-india-plans-to-wipe-out-blac k-money.html

[7] Anand, G. and Hari, K. (2016) Indian Vendors See Empty Stores and Blame a Rupee Ban. New York Times, November 24.

https://www.nytimes.com/2016/11/24/world/asia/india-currency-narendra-modi.ht $\underline{\mathrm{ml}}$

[8] Anand, G. and Hari, K. (2017) In Its Third Month, India's Cash Shortage Begins to Bite. New York Times, January 24.

https://www.nytimes.com/2017/01/24/world/asia/in-its-third-month-indias-cash-sh ortage-begins-to-bite.html

[9] Kazmin, A. and Simon, M. (2017) India's Cash Crunch Draws to a Close. Financial Times, March 14, 6.

[10] Betz, F. (2011) Societal Dynamics. Springer, New York.

[11] Anand, G. (2017) Arun Jaitley, India's Finance Chief, Aims to Spur Economy Hit by Cash Shortage. New York Times, February 1

https://www.nytimes.com/2017/02/01/world/asia/indias-new-budget-aims-to-spureconomy-hit-hard-by-cash-shortage.html?_r=0 
Submit or recommend next manuscript to SCIRP and we will provide best service for you:

Accepting pre-submission inquiries through Email, Facebook, LinkedIn, Twitter, etc. A wide selection of journals (inclusive of 9 subjects, more than 200 journals)

Providing 24-hour high-quality service

User-friendly online submission system

Fair and swift peer-review system

Efficient typesetting and proofreading procedure

Display of the result of downloads and visits, as well as the number of cited articles Maximum dissemination of your research work

Submit your manuscript at: http://papersubmission.scirp.org/

Or contact tel@scirp.org 